\title{
Distribution and composition of the epibenthic megafauna north of Svalbard (Arctic)
}

\author{
M. Sswat • B. Gulliksen • I. Menn • A. K. Sweetman • \\ D. Piepenburg
}

Received: 13 October 2013/Revised: 19 December 2014/ Accepted: 16 January 2015

(C) Springer-Verlag Berlin Heidelberg 2015

\begin{abstract}
Benthic communities north of Svalbard are less investigated than in other Arctic shelf regions, as this area was covered by sea-ice during most of the year. Improving our knowledge on this region is timely, however, since climate change is strongly evident there, particularly with regard to the extent of sea-ice decline and its huge ecological impact on all marine biota, including the benthos. Moreover, longer ice-free periods will certainly lead to an increase in human activity levels in the area, including bottom trawling. In two adjacent shelf and slope regions off northern Svalbard, we studied the composition of
\end{abstract}

Electronic supplementary material The online version of this article (doi:10.1007/s00300-015-1645-8) contains supplementary material, which is available to authorized users.

M. Sswat $(\bowtie) \cdot$ D. Piepenburg

Department of Polar Ecology, Institute for Ecosystem Research, University of Kiel, 24118 Kiel, Germany

e-mail: michaelsswat@gmail.com

Present Address:

M. Sswat

GEOMAR, Helmholtz Centre for Ocean Research Kiel, Kiel, Germany

B. Gulliksen

Faculty of Biosciences, Fisheries and Economics, University of Tromsø, 9037 Tromsö, Norway

\section{Menn}

Greenpeace Germany, 20457 Hamburg, Germany

\section{A. K. Sweetman}

International Research Institute of Stavanger, 4070 Randaberg, Norway

\section{Piepenburg}

Alfred Wegener Institute, Helmholtz Centre for Polar and Marine Research, 27570 Bremerhaven, Germany epibenthic megafauna and seafloor habitat structures by analyzing seabed images taken with both still and video cameras. In addition, we also used an Agassiz trawl to catch epibenthic organisms for ground-truthing seabedimage information. A wide variety of mostly sessile organisms 141 epibenthic taxa were identified in the images. The brittle star Ophiura sarsii and the soft coral Gersemia rubiformis were the most common species. At all stations $>300 \mathrm{~m}$ in depth, evidence of trawling activities was detected at the seabed. The distribution of the benthic fauna in the study area exhibited a clear depth zonation, mainly reflecting depth-related differences in seabed composition. We conclude that natural factors determining the composition of the seafloor mostly affect the distribution and composition of epibenthic assemblages. Anthropogenic impact indicated by the trawl scours found is likely also important at smaller spatial scales.

Keywords Arctic - Svalbard E Epibenthic megafauna . Depth $\cdot$ Zonation $\cdot$ Community structure $\cdot$ Trawling

\section{Introduction}

The knowledge on Arctic benthic ecosystems, their functioning and drivers has strongly increased in the past two decades (Piepenburg 2005), especially for the regions off Svalbard and the northern Barents Sea (Piepenburg et al. 2011). The majority of the studies focused on the structure of benthic communities in the fjords of Spitsbergen (Holte and Gulliksen 1998; Wlodarska-Kowalczuk et al. 1998; Hop et al. 2002; Kendall et al. 2003; Wlodarska-Kowalczuk and Pearson 2004; Renaud et al. 2007), off the western coast of Spitsbergen (Blacker 1957, 1965), and on the shelf break of the Fram Strait (Weslawski et al. 2003; 
Wlodarska-Kowalczuk and Pearson 2004). The deep-sea benthos of the eastern Fram Strait have been intensively investigated in the course of the long-term HAUSGARTEN project (Soltwedel et al. 2005, 2009; Hoste et al. 2007; Budaeva et al. 2008; Bergmann et al. 2009, 2011; van Oevelen et al. 2011). Other benthic studies have concentrated on the Barents Sea (Zenkevich 1963; Antipova 1975; Carroll et al. 2008; Cochrane et al. 2009). In comparison, the waters north of Svalbard have been much less investigated, since this region was covered by sea-ice during most of the year before the onset of the general seaice decline in the Arctic (ACIA 2004).

Improving our knowledge on the area north of Svalbard is timely, however, since it belongs to the Arctic sea regions where climate change is strongly evident (IPCC 2007), particularly with regard to the extent of sea-ice decline (Onarheim et al. 2014) and its huge ecological impact on all marine biota, including the benthos (Piepenburg 2005). Moreover, longer ice-free periods will certainly lead to an increase in human activity levels, in Arctic seas in general and the waters north of Svalbard in particular, including bottom trawling (ACIA 2004). This development will exert additional anthropogenic pressure on the marine ecosystems by either direct top-down effects of the fishery or indirect bottom-up effects by subsequent changes in trophic relationships or, most likely, the combination of both (Renaud et al. 2008; Perry et al. 2010). To document such direct anthropogenic impact on the benthos, field studies are necessary to document the current status of the threatened habitats.

The largely sessile mode of life and relatively long life spans of macro- and megabenthic fauna are biological traits that make these animals, at a scale of either organisms or communities, useful for detection of time-integrated responses to alterations in environmental conditions (Pearson and Barnett 1987; Underwood 1996). Therefore, the composition, diversity, abundance and biomass of macro- and megabenthic benthic communities have often been used as sensitive indicators of natural decadal-scale environmental change (e.g., Reise and Schubert 1987; Kröncke 1995; Kröncke et al. 1998, 2001; Tunberg and Nelson 1998; Gröger and Rumohr 2006) and of the ecological impacts of human activities like fishing and eutrophication (e.g., Pearson and Rosenberg 1978; Underwood 1996; Pearson and Mannvik 1998; Beukema et al. 2002; Carroll et al. 2003; Kaiser et al. 2006).

The main objective of our field study was to provide a qualitative and quantitative inventory of the epibenthic megafauna communities of the shelf and upper slope north of Svalbard. In addition, we elucidated the influence of environmental factors (water depth, seabed properties) on the faunal distribution and composition. Moreover, we investigated the evidence of trawling activities in the study area. Our study was aimed to provide baseline information on the current status of the benthos in the target area that can be used to detect the effects of future anthropogenic and natural impacts in the Arctic.

\section{Materials and methods}

\section{Study area}

The study was carried out in the region north of Svalbard, which features the continental shelf, deep shelf troughs and the upper continental slope (Fig. 1). It is characterized by the close juxtaposition of different water masses. Water of Atlantic origin, transported northward with the Spitsbergen Current and sinking on its way eastward below the sea surface, influences the northwestern region, while Arctic waters prevail in the southeastern region (Fig. 1). This, together with the complex shelf geomorphology and the seasonal dynamics of sea-ice cover, results in diverse environmental conditions (Carroll et al. 2008). Moreover, this area is affected by a particularly profound decrease in sea-ice cover. The decline is evident over the entire year but is most pronounced in winter, in contrast to the summer melts in the central Arctic Ocean (Onarheim et al. 2014). The region is part of the northern Barents Sea shelf, which is generally characterized by a relatively high average productivity of $93 \mathrm{~g} \mathrm{C} \mathrm{m}^{2}$ year $^{-1}$, accounting for $49 \%$ of the total Arctic shelf primary production (Sakshaug 2004; Wassmann et al. 2006). Gulliksen et al. (1999) reported a total of 363 species of marine benthic macro-organisms to occur in the study area.

\section{Field sampling}

Epibenthic megafauna communities were investigated during the Greenpeace Arctic Expedition of MS "Esperanza" in June 2010. A sonde equipped with both a video and a still camera was lowered vertically from the drifting ship (Table 1) at a total of 22 stations along bottom transects with lengths ranging from 0.22 to 2.97 nautical miles (mean: $1.2 \mathrm{~nm}$ ) at water depths between 50 and $450 \mathrm{~m}$ (Fig. 1). Continuous video footage was obtained by the sonde's standard-definition composite PAL video camera (576i; 576 interlaced lines), towed $1 \mathrm{~m}$ above the ground and looking at the seabed at an approximate angle of $45^{\circ}$. In addition, high-resolution still pictures were taken by the operator using an oblique-mounted still camera $(17-\mathrm{mm}$ lens, 10.5 Mega Pixel) fixed above the video camera, whenever interesting organisms or habitat features were detected in the real-time video footage.

In September 2011, additional seabed still photographs were taken by means of another drop-camera system 
Fig. 1 Location of sampling stations off northern Svalbard visited in 2010 and 2011. Lengths of video/photograph transects are indicated by red lines. (Color figure online)

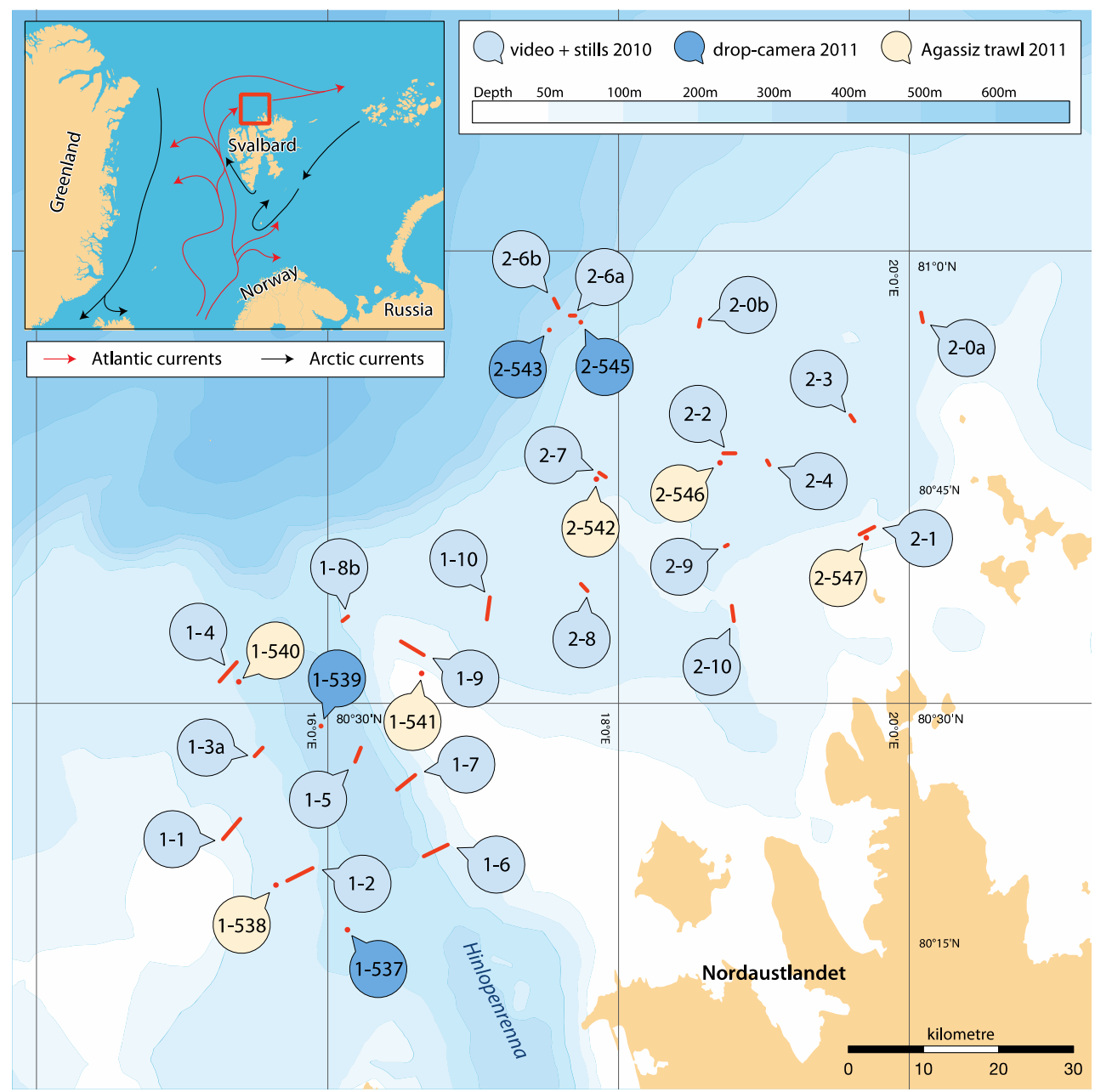

during the cruise of the Norwegian RV "Helmer Hanssen" to northern Svalbard at four stations, using the approach described by Sweetman and Chapman (2011).

In addition, Agassiz trawl (AGT) samples were collected in September 2011 at six selected stations (Fig. 1; Table 1), to aid the taxonomic identification of organisms visible in the seabed images. These stations were chosen to be as close as possible to the imaging stations visited in 2010, which were most diverse in terms of the composition of epibenthic taxa (stations 1-2, 1-4, 1-9, 2-1, 2-2, and 2-7). The width of the AGT frame was $2 \mathrm{~m}$, and the mesh size of the net was $2 \mathrm{~cm}$. All AGT hauls lasted 25 min (time of trawling over the bottom).

\section{Image analysis}

All epibenthic megafauna visible in the seabed images and collected from AGT catches were identified to the lowest possible taxonomic level, using various references (Gulliksen et al. 1999; Gulliksen and Svensen 2004; Moen and Svensen 2004; Appeltans et al. 2012; Palomares and Pauly 2014; http:// hercules.kgs.ku.edu/hexacoral/anemone2/index.cfm). Furthermore, taxonomic specialists were consulted for expert advice (personal communication: J. Berge, T. Brattegard, S. Cochrane, P. Kuklinski, A. Plotkin, P. Renaud, A.H. Tandberg, M. Włodarska-Kowalczuk).

Based on the height over ground and the field of vision of the obliquely oriented video camera, each frame shot approximately depicts a rectangular seabed area with a baseline of $1 \mathrm{~m}$ and a "depth" (in drift direction) of $1.2 \mathrm{~m}$. The latter was estimated using the drift speed of the sonde (grand average across all stations: $0.6 \pm 0.4 \mathrm{~m} \mathrm{~s}^{-1} \mathrm{SD}$, range: 0.1 to $1.8 \mathrm{~m} \mathrm{~s}^{-1}$ ) and the time needed to cross the area imaged in a frame shot, which was taken from the video frame time stamps. Therefore, each frame shot depicted a seabed area of approximately $1.2 \mathrm{~m}^{2}$. A subset of frame shots was randomly chosen for each station for further image analysis to gain for quantitative information on the abundances of ten higher taxa that could be unequivocally identified in the frame shots: poriferans, soft corals (mainly of Gersemia rubiformis), actiniarians, decapod crustaceans (mostly Pandalus borealis), crinoids, 
Table 1 Information on stations where seabed images and Agassiz trawl catches were taken in 2010 and 2011

\begin{tabular}{|c|c|c|c|c|c|c|c|c|}
\hline Station & & & \multirow[t]{2}{*}{$\begin{array}{l}\text { Mean } \\
\text { depth } \\
\text { in } m\end{array}$} & \multirow[t]{2}{*}{$\begin{array}{l}\text { Depth } \\
\text { range } \\
\text { in } \mathrm{m}\end{array}$} & \multirow[t]{2}{*}{ Zone } & \multirow[t]{2}{*}{$\begin{array}{l}\text { Transect } \\
\text { length in } \\
\text { nautical miles }\end{array}$} & \multirow[t]{2}{*}{$\begin{array}{l}\text { Number } \\
\text { of stills }\end{array}$} & \multirow[t]{2}{*}{$\begin{array}{l}\text { Number of } \\
\text { video frame } \\
\text { shots } \\
\text { analyzed }\end{array}$} \\
\hline $\begin{array}{l}\text { Photograph /video } \\
\text { sonde casts }(2010)\end{array}$ & Start of transect & End of transect & & & & & & \\
\hline \multirow[t]{2}{*}{$1-1$} & $80^{\circ} 20.723^{\prime} \mathrm{N}$ & $80^{\circ} 22.125^{\prime} \mathrm{N}$ & 94 & $81-110$ & Shallow & 2.97 & 52 & 45 \\
\hline & $15^{\circ} 16.764^{\prime} \mathrm{E}$ & $15^{\circ} 24.120^{\prime} \mathrm{E}$ & & & & & & \\
\hline \multirow[t]{2}{*}{$1-8 b$} & $80^{\circ} 35.640^{\prime} \mathrm{N}$ & $80^{\circ} 35.876^{\prime} \mathrm{N}$ & 56 & $51-60$ & Shallow & 0.95 & 54 & 19 \\
\hline & $16^{\circ} 06.231^{\prime} \mathrm{E}$ & $16^{\circ} 08.432^{\prime} \mathrm{E}$ & & & & & & \\
\hline \multirow[t]{2}{*}{$1-9$} & $80^{\circ} 33.256^{\prime} \mathrm{N}$ & $80^{\circ} 34.201^{\prime} \mathrm{N}$ & 56 & $50-65$ & Shallow & 1.92 & 56 & 50 \\
\hline & $16^{\circ} 39.688^{\prime} \mathrm{E}$ & $16^{\circ} 30.270^{\prime} \mathrm{E}$ & & & & & & \\
\hline \multirow[t]{2}{*}{$2-1$} & $80^{\circ} 40.098^{\prime} \mathrm{N}$ & $80^{\circ} 40.609^{\prime} \mathrm{N}$ & 73 & $51-87$ & Shallow & 1.12 & 29 & 29 \\
\hline & $19^{\circ} 41.817^{\prime} \mathrm{E}$ & $19^{\circ} 47.894^{\prime} \mathrm{E}$ & & & & & & \\
\hline \multirow[t]{2}{*}{$2-2$} & $80^{\circ} 46.764^{\prime} \mathrm{N}$ & $80^{\circ} 46.797^{\prime} \mathrm{N}$ & 87 & $84-90$ & Shallow & 0.83 & 30 & 31 \\
\hline & $18^{\circ} 43.116^{\prime} \mathrm{E}$ & $18^{\circ} 48.271^{\prime} \mathrm{E}$ & & & & & & \\
\hline \multirow[t]{2}{*}{$2-3$} & $80^{\circ} 49.280^{\prime} \mathrm{N}$ & $80^{\circ} 48.886^{\prime} \mathrm{N}$ & 123 & $136-109$ & Shallow & 0.80 & 20 & 19 \\
\hline & $19^{\circ} 35.563^{\prime} \mathrm{E}$ & $19^{\circ} 37.158^{\prime} \mathrm{E}$ & & & & & & \\
\hline \multirow[t]{2}{*}{$2-4$} & $80^{\circ} 46.251^{\prime} \mathrm{N}$ & $80^{\circ} 46.031^{\prime} \mathrm{N}$ & 89 & $87-90$ & Shallow & 0.80 & 37 & 30 \\
\hline & $19^{\circ} 01.321^{\prime} \mathrm{E}$ & $19^{\circ} 02.183^{\prime} \mathrm{E}$ & & & & & & \\
\hline \multirow[t]{2}{*}{$2-7$} & $80^{\circ} 45.468^{\prime} \mathrm{N}$ & $80^{\circ} 45.206^{\prime}$ & 113 & $111-114$ & Shallow & 0.67 & 37 & 31 \\
\hline & $17^{\circ} 52.023^{\prime} \mathrm{E}$ & $17^{\circ} 54.672^{\prime}$ & & & & & & \\
\hline \multirow[t]{2}{*}{$2-8$} & $80^{\circ} 38.118^{\prime} \mathrm{N}$ & $80^{\circ} 37.577^{\prime} \mathrm{N}$ & 138 & $132-144$ & Shallow & 0.74 & 9 & 30 \\
\hline & $17^{\circ} 44.412^{\prime} \mathrm{E}$ & $17^{\circ} 47.339^{\prime} \mathrm{E}$ & & & & & & \\
\hline \multirow[t]{2}{*}{$2-9$} & $80^{\circ} 40.600^{\prime} \mathrm{N}$ & $80^{\circ} 40.700^{\prime}$ & 90 & 90 & Shallow & 0.22 & 24 & 31 \\
\hline & $18^{\circ} 43.900^{\prime} \mathrm{E}$ & $18^{\circ} 45.100^{\prime} \mathrm{E}$ & & & & & & \\
\hline \multirow[t]{2}{*}{$2-10$} & $80^{\circ} 36.612^{\prime} \mathrm{N}$ & $80^{\circ} 35.586^{\prime} \mathrm{N}$ & 58 & $55-60$ & Shallow & 1.31 & 26 & 30 \\
\hline & $18^{\circ} 46.681^{\prime} \mathrm{E}$ & $18^{\circ} 47.541^{\prime} \mathrm{E}$ & & & & & & \\
\hline \multirow[t]{2}{*}{$1-2$} & $80^{\circ} 17.804^{\prime} \mathrm{N}$ & $80^{\circ} 18.668^{\prime} \mathrm{N}$ & 176 & $163-193$ & Intermediate & 1.94 & 39 & 46 \\
\hline & $15^{\circ} 43.429^{\prime} \mathrm{E}$ & $15^{\circ} 53.746^{\prime} \mathrm{E}$ & & & & & & \\
\hline \multirow[t]{2}{*}{$1-3 a$} & $80^{\circ} 26.434^{\prime} \mathrm{N}$ & $80^{\circ} 26.992^{\prime} \mathrm{N}$ & 180 & $170-190$ & Intermediate & 0.93 & 68 & 48 \\
\hline & $15^{\circ} 28.855^{\prime} \mathrm{E}$ & $15^{\circ} 33.335^{\prime} \mathrm{E}$ & & & & & & \\
\hline \multirow[t]{2}{*}{$1-4$} & $80^{\circ} 32.846^{\prime} \mathrm{N}$ & $80^{\circ} 31.543^{\prime} \mathrm{N}$ & 193 & $160-251$ & Intermediate & 1.77 & 41 & 40 \\
\hline & $15^{\circ} 22.637^{\prime} \mathrm{E}$ & $15^{\circ} 15.405^{\prime} \mathrm{E}$ & & & & & & \\
\hline \multirow[t]{2}{*}{$1-10$} & $80^{\circ} 37.222^{\prime} \mathrm{N}$ & $80^{\circ} 35.664^{\prime} \mathrm{N}$ & 161 & $150-176$ & Intermediate & 1.59 & 32 & 40 \\
\hline & $17^{\circ} 06.948^{\prime} \mathrm{E}$ & $17^{\circ} 05.777^{\prime} \mathrm{E}$ & & & & & & \\
\hline $2-0 \mathrm{a}$ & $80^{\circ} 55.972^{\prime} \mathrm{N}$ & $80^{\circ} 55.365^{\prime} \mathrm{N}$ & 112 & $150-174$ & Intermediate & 0.65 & 13 & 25 \\
\hline & $20^{\circ} 04.843^{\prime} \mathrm{E}$ & $20^{\circ} 05.516^{\prime} \mathrm{E}$ & & & & & & \\
\hline $2-0 b$ & $80^{\circ} 55.650^{\prime} \mathrm{N}$ & $80^{\circ} 55.112^{\prime} \mathrm{N}$ & 169 & $165-176$ & Intermediate & 0.59 & 40 & 31 \\
\hline & $18^{\circ} 33.766^{\prime} \mathrm{E}$ & $18^{\circ} 33.198^{\prime} \mathrm{E}$ & & & & & & \\
\hline $2-6 a$ & $80^{\circ} 55.845^{\prime} \mathrm{N}$ & $80^{\circ} 55.782^{\prime} \mathrm{N}$ & 238 & 238 & Intermediate & 0.48 & 20 & 11 \\
\hline & $17^{\circ} 42.126^{\prime} \mathrm{E}$ & $17^{\circ} 39.914^{\prime} \mathrm{E}$ & & & & & & \\
\hline $1-5$ & $80^{\circ} 26.965^{\prime} \mathrm{N}$ & $80^{\circ} 26.027^{\prime} \mathrm{N}$ & 398 & $366-446$ & Deep & 1.03 & 10 & 43 \\
\hline & $16^{\circ} 13.746^{\prime} \mathrm{E}$ & $16^{\circ} 11.269^{\prime} \mathrm{E}$ & & & & & & \\
\hline $2-6 b$ & $80^{\circ} 56.919^{\prime} \mathrm{N}$ & $80^{\circ} 56.328^{\prime} \mathrm{N}$ & 386 & $368-405$ & Deep & 0.66 & 9 & 18 \\
\hline & $17^{\circ} 33.431^{\prime} \mathrm{E}$ & $17^{\circ} 35.323^{\prime} \mathrm{E}$ & & & & & & \\
\hline $1-6$ & $80^{\circ} 19.477^{\prime} \mathrm{N}$ & $80^{\circ} 20.294^{\prime} \mathrm{N}$ & 193 & $87-277$ & Transition & 1.90 & 63 & 46 \\
\hline & $16^{\circ} 39.785^{\prime} \mathrm{E}$ & $16^{\circ} 49.505^{\prime} \mathrm{E}$ & & & & & & \\
\hline $1-7$ & $80^{\circ} 24.123^{\prime} \mathrm{N}$ & $80^{\circ} 25.141^{\prime} \mathrm{N}$ & 202 & $90-330$ & Transition & 1.64 & 58 & 46 \\
\hline & $16^{\circ} 28.468^{\prime} \mathrm{E}$ & $16^{\circ} 36.176^{\prime} \mathrm{E}$ & & & & & & \\
\hline
\end{tabular}


Table 1 continued

\begin{tabular}{|c|c|c|c|c|c|c|c|}
\hline \multicolumn{2}{|l|}{ Station } & \multirow{3}{*}{$\begin{array}{l}\text { Mean } \\
\text { depth } \\
\text { in } m\end{array}$} & \multirow{3}{*}{$\begin{array}{l}\text { Depth } \\
\text { range } \\
\text { in } \mathrm{m}\end{array}$} & \multirow{3}{*}{$\begin{array}{l}\text { Zone } \\
\text { Intermediate }\end{array}$} & \multirow{3}{*}{$\begin{array}{l}\text { Transect } \\
\text { length in } \\
\text { nautical miles }\end{array}$} & \multirow{3}{*}{$\begin{array}{l}\begin{array}{l}\text { Number } \\
\text { of stills }\end{array} \\
44\end{array}$} & \multirow{3}{*}{$\begin{array}{l}\text { Number of } \\
\text { video frame } \\
\text { shots } \\
\text { analyzed } \\
\end{array}$} \\
\hline Drop-camera casts (2011) & Position & & & & & & \\
\hline $2-545$ & $\begin{array}{l}80^{\circ} 55.140^{\prime} \mathrm{N} \\
17^{\circ} 55.236^{\prime} \mathrm{E}\end{array}$ & & & & & & \\
\hline $1-537$ & $\begin{array}{l}80^{\circ} 14.939^{\prime} \mathrm{N} \\
16^{\circ} 08.108^{\prime} \mathrm{E}\end{array}$ & 286 & 285 & Deep & & 3 & \\
\hline $1-539$ & $\begin{array}{l}80^{\circ} 29.989^{\prime} \mathrm{N} \\
15^{\circ} 58.301^{\prime} \mathrm{E}\end{array}$ & 350 & 349 & Deep & & 8 & \\
\hline $2-543$ & $\begin{array}{l}80^{\circ} 54.132^{\prime} \mathrm{N} \\
17^{\circ} 27.431^{\prime} \mathrm{E}\end{array}$ & 361 & 360 & Deep & & 12 & \\
\hline Agassiz trawl hauls (2011) & Position & & & & & & \\
\hline $1-541$ & $\begin{array}{l}80^{\circ} 33.180^{\prime} \mathrm{N} \\
16^{\circ} 38.811^{\prime} \mathrm{E}\end{array}$ & 56 & 56 & Shallow & & & \\
\hline $2-542$ & $\begin{array}{l}80^{\circ} 44.670^{\prime} \mathrm{N} \\
17^{\circ} 51.107^{\prime} \mathrm{E}\end{array}$ & 104 & 104 & Shallow & & & \\
\hline $2-546$ & $\begin{array}{l}80^{\circ} 45.832^{\prime} \mathrm{N} \\
18^{\circ} 43.705^{\prime} \mathrm{E}\end{array}$ & 95 & 95 & Shallow & & & \\
\hline $2-547$ & $\begin{array}{l}80^{\circ} 39.893^{\prime} \mathrm{N} \\
19^{\circ} 43.391^{\prime} \mathrm{E}\end{array}$ & 81 & 81 & Shallow & & & \\
\hline $1-538$ & $\begin{array}{l}80^{\circ} 17.392^{\prime} \mathrm{N} \\
15^{\circ} 44.515^{\prime} \mathrm{E}\end{array}$ & 164 & 164 & Intermediate & & & \\
\hline $1-540$ & $\begin{array}{l}80^{\circ} 32.312^{\prime} \mathrm{N} \\
15^{\circ} 21.697^{\prime} \mathrm{E}\end{array}$ & 215 & 215 & Intermediate & & & \\
\hline
\end{tabular}

ophiuroids, asteroids, echinoids, ascidians and fishes. The number of selected frame shots depended on the total length of the video transect and hence overall area imaged, of each station. It was chosen to represent approximately $1 / 60(\sim 2 \%)$ of the overall station transect length. Using this approach, eleven to 51 separate "frame shots" (depending on the video transect length) were randomly selected for each station based on the time stamps of the first frame in the sequence (Table 1). The selected 902 frame shots from 26 stations were processed by means of Adobe Photoshop CS5 to enhance overall image quality with regard to brightness, contrast, resolution, hue, etc. Photoshop's count tool was used to enumerate the numbers of benthic specimens visible in each frame shot. In case of colonial organisms (sponges, soft corals and ascidians), we counted the number of colonies. All counts were standardized to numbers $\mathrm{m}^{-2}$.

In addition, the still photographs taken in 2011 were analyzed quantitatively for abundances of epibenthic organisms visible in the images. In contrast to the video frame shots, the seabed area depicted by each photograph could be assessed with high precision due to the presence of 2 lasers mounted $26 \mathrm{~cm}$ apart from each other, providing a scale in each photograph (Sweetman and Chapman 2011). The outer margins of the photographs were not considered in the analysis to avoid systematic errors possibly introduced by any peripheral image bias. We did not quantitatively analyze the still photographs taken in 2010 because they were not taken at random. Their "qualitative" analysis, however, provided presence-absence data for each station at a much finer taxonomic, often "putativespecies," level than the quantitative data gained in the video image analysis.

Finally, the type of seabed substrate was determined in each frame shot and photograph, using a modified classification scheme proposed by Hiscock (1996). It is based on the presence-absence of different substrate types: gravel, sand, mud, and-as structuring substrates-boulders (larger than $50 \mathrm{~cm}$ ), stones $(15-50 \mathrm{~cm}$ size) and pebbles ( $<15 \mathrm{~cm}$ in size). Since usually more than one substrate type occurred in a single picture, the frequencies of each substrate type across all frame shots and still photographs from 2011 were calculated for each station. 
Data analysis

The faunistic analyses of video and still images yielded two biotic datasets. The first one was based on the analysis of still pictures taken in 2010 and contains qualitative presence-absence data at a fine taxonomic level. The second set was produced through the analysis of video frame shots, as well as still photographs from 2011, and features the quantitative abundance values at a coarser taxonomic level (see above). Information on abiotic seabed substrate composition, which contained frequencies of substrate types for each station, was stored in a third dataset.

These three datasets were subjected to multivariate statistical analysis, using the software package PRIMER v6 (Clarke and Gorley 2006). The stations were a priori allocated to three depth zones to study depth-related shifts in benthic community and habitat structure: "Shallow" (50-150 m), "Intermediate" (150 and $250 \mathrm{~m}$ ) and "Deep" (250-450 m). Two stations, which encompassed a withinstation depth range of 90 to $330 \mathrm{~m}$ (thus covering all three depth zones), were excluded from the statistical analysis and were only used for the compilation of the overall taxa list.

Bray-Curtis similarities between all stations were calculated for both biotic datasets. For the quantitative dataset, abundance values were square root transformed prior to the computation of similarities to downscale the effect of very abundant taxa in the analysis. For the abiotic dataset, Euclidean distances were computed as resemblance measures. For both the qualitative and quantitative biotic dataset, analysis of similarities (ANOSIM) was used to test for significant differences $(p \leq 0.05)$ among depth zones. RELATE tests were applied to test whether there was a significant correlation between the among-station variation in faunal community composition and seabed structure. BEST analysis was performed to identify the set of abiotic seabed features that are most correlated with-and thus very likely best explains - the spatial pattern of epibenthic composition. The qualitative biotic dataset was analyzed by means of SIMPER analysis to determine those taxa that could be used as indicator organisms for a given depth zone.

\section{Results}

\section{Seabed characteristics}

The composition of the seabed did not differ markedly among stations at shallow and intermediate depths, where it was likewise characterized by a dominance of sandy sediments, with occasional boulders and stones lying at the surface (Fig. 2). Exceptions were shallow station 2-3 and intermediate stations 2-0a, 2-0b, 2-545, which primarily featured muddy sediments. The two transition stations showed a mixture of the other zones, but the seabed at station 1-7 largely consisted of mud. Deep stations were generally characterized by a muddy seafloor surface, with only very few stones. Overall, the among-zone differences in seabed composition are statistically significant (Global ANOSIM R: $0.424 ; p=0.001$ ). In the MDS plot visualizing the among-station resemblance pattern in terms of

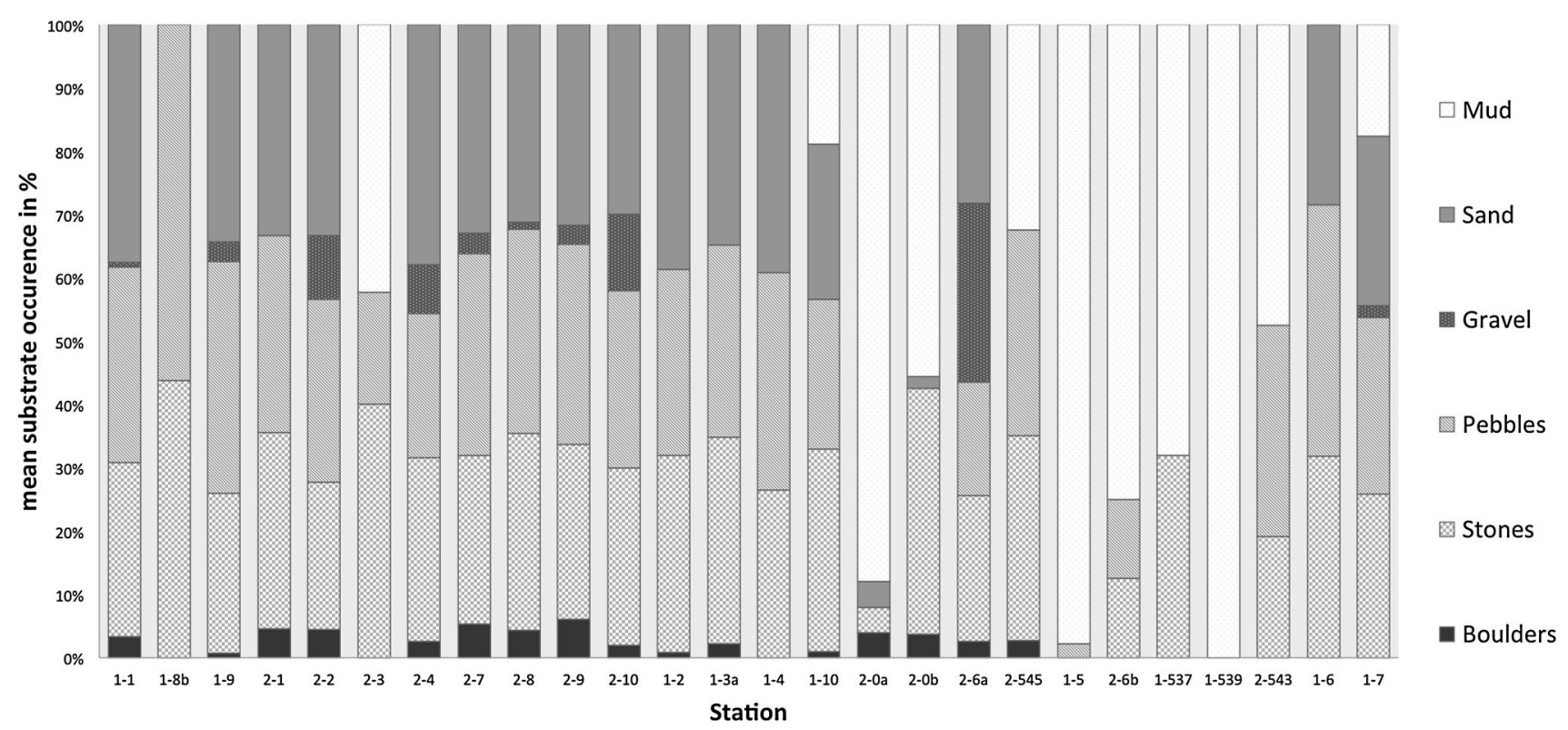

Fig. 2 Seabed composition in seabed images taken off northern Svalbard in 2010 and 2011, according to percentage frequencies of substrate types determined using a modified classification scheme proposed by Hiscock (1996) 


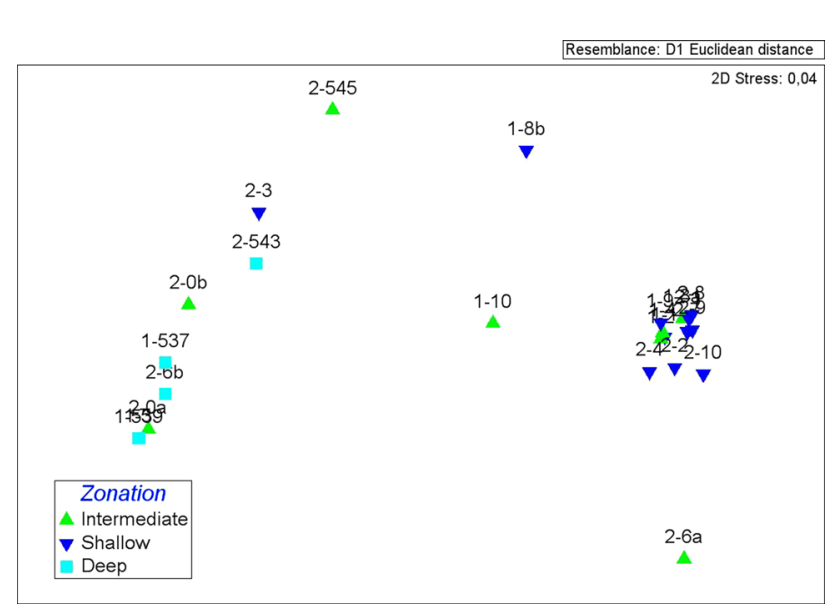

Fig. 3 MDS plot visualizing the resemblances (quantified as Euclidean distances) among stations in terms of the composition of the seabed analyzed in images taken off northern Svalbard in 2010 and 2011

seabed features (Fig. 3), pronounced variations among depth zones are also detectable: A well-defined group of deep stations is clearly separated from the shallow stations, while intermediate stations are widely distributed across the plot, indicating that they are much more heterogeneous in seabed composition than the stations in the other depth zones.

Faunal composition

\section{Seabed images}

A total of 141 taxa (including 26 poriferans, 31 cnidarians, 14 mollusks, one brachiopod, seven bryozoans, five polychaetes, one nemertine, eight arthropods, 23 echinoderms, eight ascidians and 17 fishes) were identified in the seabed images taken at 26 stations off northern Svalbard (Online Resource 1). The number of taxa recorded per station ranged from three at station 1-537 to 68 at station 1-3a, with an average of $32 \pm 19$ SD (Online Resource 1). The brittle star Ophiura sarsii was the most common species, being present in 21 stations, followed by the soft coral $G$. rubiformis that was found at 19 stations (Table 2). The two commercially utilized invertebrates, the prawn $P$. borealis and the scallop Chlamys islandica, occurred at depths of 87-405 and 50-277 m, respectively (Online Resource 1). A total of 31 taxa were recorded at only a single station (Online Resource 1).

More than one-third of the 141 taxa detected in the seabed images were found at the most diverse shallow stations (Figs. 4a, 5a), and up to roughly half of them at intermediate stations (Figs. 4b, 5b). In comparison, the deep stations were clearly less diverse, featuring $<10 \%$ of all taxa found in all three depth zones (Figs. 4c, 5c).
The composition of epibenthic megafauna differed significantly among depth zones (ANOSIM Global R: 0.545; $p=0.001$ ) (Fig. 6). Pairwise ANOSIM tests indicated that shallow and intermediate stations were comparatively similar in composition, while deep stations were clearly different from the other zones. SIMPER analysis revealed that in the shallow zone, $O$. sarsii, Strongylocentrotus sp., G. rubiformis and Hydroides norvegicus were most frequent, whereas in the intermediate zone, G. rubiformis, Hornera sp. and Ophiopholis aculeata prevailed; the deep zone was characterized by $P$. borealis as well as $O$. sarsii (Table 3). The biotic distribution pattern, based on presence-absence data, was significantly related to the amongstation variation in abiotic seabed composition (RELATE test $r=0.518 ; p=0.001$ ). According to the BEST analysis, it was explained best by the presence of stones and pebbles $($ BEST analysis correlation $=0.581)$.

\section{Agassiz trawl catches}

A total of 107 taxa were identified in the AGT catches (Online Resource 1). Of these, 50 taxa were also found in seabed images and 41 of these taxa at the same stations. Ten taxa were present at more than three AGT stations. The brittle star O. aculeata and the sea urchin Strongylocentrotus sp. were present at all six stations, and the bryozoan Myriapora sp. occurred at five stations. The highest numbers of taxa $(>40)$ were recorded at AGT stations 540 (corresponding to seabed-image station 1-4) and 541 (corresponding to seabed-image station 1-9), while the lowest number of taxa (16) was collected at AGT station 542 (corresponding to seabed-image station 2-7) (Fig. 7a; Online Resource 1). Porifera dominated the AGT catches at stations 538 and 540, while station 541 was characterized by more equally distributed numbers of Cnidaria, Mollusca, Arthropoda and Echinodermata (Fig. 7a). Cnidaria dominated Station 542, Echinodermata station 546, and fairly equal proportions of Porifera, Cnidaria, Arthropoda and Echinodermata were recorded at station 547(Fig. 7a). Overall, the coarse-level taxonomic composition of the fauna recorded in AGT catches was quite similar to that identified in the seabed images (Fig. 7b).

Faunal abundance

Ophiuroids were most abundant at all seabed-image stations, together with ascidians, which showed higher variations in abundance than the ophiuroids (both with up to almost 40 ind $\mathrm{m}^{-2}$; Table 4). Crinoids, actinians, poriferans and echinoids were also abundant (up to 4.8 and 8.0 ind $\mathrm{m}^{-2}$ ); $1.8-1.4$ ind $\mathrm{m}^{-2}$ were the highest abundances for shrimps and soft corals, while asteroids and 
Table 2 Presence-absence data of all megabenthic taxa, which were present in seabed images and Agassiz trawl catches taken north of Svalbard in 2010 and 2011 at more than ten stations

\begin{tabular}{|c|c|c|c|c|c|c|c|c|c|c|c|}
\hline \multirow{2}{*}{$\begin{array}{l}\text { Depth zone } \\
\text { Shallow }\end{array}$} & \multirow{2}{*}{$\begin{array}{l}\text { Station } \\
1-1\end{array}$} & \multirow{2}{*}{$\begin{array}{l}\begin{array}{l}\text { Lafoeina } \\
\text { maxima }\end{array} \\
1\end{array}$} & $\begin{array}{l}\text { Gersemia } \\
\text { rubiformis }\end{array}$ & \multicolumn{2}{|c|}{$\begin{array}{l}\text { Ptychogastria } \\
\text { polaris }\end{array}$} & $\begin{array}{l}\text { Hormathia } \\
\text { sp. }\end{array}$ & \multirow{2}{*}{$\begin{array}{l}\text { Urticina } \\
\text { sp. }\end{array}$} & \multirow{2}{*}{$\begin{array}{l}\begin{array}{l}\text { Hydroides } \\
\text { norvegica }\end{array} \\
1\end{array}$} & \multirow{2}{*}{$\begin{array}{l}\begin{array}{l}\text { Sabellida } \\
\text { indet. }\end{array} \\
1\end{array}$} & \multirow{2}{*}{$\begin{array}{l}\begin{array}{l}\text { Lebbeus } \\
\text { cf. polaris }\end{array} \\
0\end{array}$} & \multirow{2}{*}{$\frac{\begin{array}{l}\text { Balanus } \\
\text { cf. balanus }\end{array}}{1}$} \\
\hline & & & 1 & 0 & 1 & 1 & & & & & \\
\hline & $1-8 b$ & 1 & 1 & 0 & 1 & 1 & 1 & 1 & 1 & 1 & 1 \\
\hline & $1-9$ & 1 & 1 & 0 & 0 & 0 & 1 & 1 & 1 & 1 & 1 \\
\hline & $2-1$ & 1 & 1 & 1 & 1 & 1 & 1 & 1 & 1 & 1 & 1 \\
\hline & $2-2$ & 1 & 1 & 1 & 1 & 1 & 0 & 1 & 1 & 1 & 1 \\
\hline & $2-3$ & 1 & 1 & 1 & 1 & 1 & 0 & 1 & 0 & 0 & 0 \\
\hline & $2-4$ & 0 & 1 & 1 & 1 & 1 & 0 & 1 & 0 & 1 & 0 \\
\hline & $2-7$ & 1 & 1 & 1 & 1 & 1 & 1 & 1 & 1 & 1 & 0 \\
\hline & $2-8$ & 0 & 0 & 1 & 0 & 0 & 0 & 0 & 0 & 0 & 1 \\
\hline & $2-9$ & 1 & 1 & 1 & 1 & 1 & 1 & 1 & 0 & 1 & 1 \\
\hline & $2-10$ & 0 & 1 & 1 & 1 & 1 & 1 & 1 & 0 & 1 & 1 \\
\hline \multirow[t]{8}{*}{ Intermediate } & $1-2$ & 0 & 1 & 1 & 1 & 1 & 1 & 1 & 1 & 0 & 0 \\
\hline & $1-3 a$ & 1 & 1 & 1 & 1 & 1 & 1 & 1 & 1 & 1 & 1 \\
\hline & $1-4$ & 1 & 1 & 0 & 0 & 0 & 0 & 1 & 1 & 0 & 1 \\
\hline & $1-10$ & 1 & 1 & 1 & 1 & 1 & 1 & 0 & 0 & 0 & 0 \\
\hline & $2-0 \mathrm{a}$ & 0 & 1 & 1 & 1 & 1 & 1 & 0 & 0 & 0 & 0 \\
\hline & $2-0 \mathrm{~b}$ & 0 & 1 & 0 & 1 & 1 & 1 & 1 & 1 & 1 & 1 \\
\hline & $2-6 a$ & 0 & 1 & 0 & 0 & 0 & 0 & 1 & 0 & 1 & 1 \\
\hline & $2-545$ & 0 & 1 & 1 & 1 & 1 & 1 & 1 & 1 & 0 & 0 \\
\hline \multirow[t]{5}{*}{ Deep } & $1-5$ & 0 & 1 & 0 & 0 & 0 & 0 & 0 & 1 & 0 & 0 \\
\hline & $2-6 b$ & 0 & 0 & 1 & 0 & 0 & 0 & 0 & 1 & 0 & 0 \\
\hline & $1-537$ & 0 & 0 & 0 & 0 & 0 & 0 & 0 & 0 & 0 & 0 \\
\hline & $1-539$ & 0 & 0 & 0 & 0 & 0 & 0 & 0 & 0 & 0 & 0 \\
\hline & $2-543$ & 0 & 0 & 1 & 1 & 1 & 0 & 0 & 0 & 0 & 0 \\
\hline \multirow[t]{2}{*}{ Transition } & $1-6$ & 1 & 1 & 1 & 1 & 1 & 1 & 1 & 1 & 1 & 1 \\
\hline & $1-7$ & 1 & 1 & 1 & 1 & 1 & 1 & 1 & 1 & 1 & 1 \\
\hline All & Sum & 11 & 19 & 15 & & 16 & 13 & 16 & 13 & 11 & 12 \\
\hline Depth zone & Station & $\begin{array}{l}\text { Strongyloc } \\
\text { sp. }\end{array}$ & entrotus & $\begin{array}{l}\text { Ophiopholis } \\
\text { aculeata }\end{array}$ & $\begin{array}{l}\text { Ophiura } \\
\text { sarsii }\end{array}$ & $\begin{array}{l}\text { a Gorgon } \\
\text { sp. }\end{array}$ & cephalus & $\begin{array}{l}\text { Heliometra } \\
\text { glacialis }\end{array}$ & $\begin{array}{l}\text { Botryllus } \\
\text { sp. }\end{array}$ & $\begin{array}{l}\text { Ascidiacea } \\
\text { indet. } 1\end{array}$ & $\begin{array}{l}\text { Leptoclinus } \\
\text { maculatus }\end{array}$ \\
\hline \multirow[t]{11}{*}{ Shallow } & $1-1$ & 1 & & 1 & 1 & 1 & & 1 & 1 & 1 & 1 \\
\hline & $1-8 b$ & 1 & & 1 & 1 & 1 & & 1 & 1 & 0 & 0 \\
\hline & $1-9$ & 1 & & 1 & 1 & 1 & & 1 & 1 & 1 & 1 \\
\hline & $2-1$ & 1 & & 1 & 1 & 1 & & 1 & 1 & 0 & 0 \\
\hline & $2-2$ & 1 & & 1 & 1 & 1 & & 1 & 1 & 0 & 1 \\
\hline & $2-3$ & 1 & & 0 & 1 & 1 & & 1 & 0 & 0 & 0 \\
\hline & $2-4$ & 0 & & 1 & 1 & 1 & & 1 & 1 & 1 & 1 \\
\hline & $2-7$ & 1 & & 1 & 1 & 0 & & 1 & 1 & 1 & 0 \\
\hline & $2-8$ & 1 & & 0 & 1 & 0 & & 0 & 1 & 0 & 0 \\
\hline & $2-9$ & 1 & & 1 & 1 & 1 & & 1 & 1 & 0 & 0 \\
\hline & $2-10$ & 1 & & 1 & 1 & 1 & & 0 & 0 & 1 & 0 \\
\hline \multirow[t]{7}{*}{ Intermediate } & $1-2$ & 1 & & 1 & 1 & 0 & & 0 & 0 & 1 & 1 \\
\hline & $1-3 a$ & 0 & & 1 & 1 & 1 & & 1 & 1 & 1 & 0 \\
\hline & $1-4$ & 0 & & 1 & 1 & 0 & & 0 & 1 & 1 & 0 \\
\hline & $1-10$ & 1 & & 1 & 1 & 0 & & 0 & 1 & 1 & 1 \\
\hline & $2-0 \mathrm{a}$ & 0 & & 0 & 0 & 1 & & 1 & 0 & 0 & 1 \\
\hline & $2-0 \mathrm{~b}$ & 0 & & 1 & 0 & 1 & & 1 & 0 & 1 & 1 \\
\hline & $2-6 a$ & 1 & & 1 & 0 & 0 & & 0 & 1 & 0 & 0 \\
\hline
\end{tabular}


Table 2 continued

\begin{tabular}{|c|c|c|c|c|c|c|c|c|c|}
\hline $\begin{array}{l}\text { Depth } \\
\text { zone }\end{array}$ & Station & $\begin{array}{l}\text { Strongylocentrotus } \\
\text { sp. }\end{array}$ & $\begin{array}{l}\text { Ophiopholis } \\
\text { aculeata }\end{array}$ & $\begin{array}{l}\text { Ophiura } \\
\text { sarsii }\end{array}$ & $\begin{array}{l}\text { Gorgonocephalus } \\
\text { sp. }\end{array}$ & $\begin{array}{l}\text { Heliometra } \\
\text { glacialis }\end{array}$ & $\begin{array}{l}\text { Botryllus } \\
\text { sp. }\end{array}$ & $\begin{array}{l}\text { Ascidiacea } \\
\text { indet. } 1\end{array}$ & $\begin{array}{l}\text { Leptoclinus } \\
\text { maculatus }\end{array}$ \\
\hline & $2-545$ & 1 & 1 & 1 & 0 & 1 & 1 & 1 & 1 \\
\hline \multirow[t]{5}{*}{ Deep } & $1-5$ & 0 & 0 & 1 & 0 & 1 & 0 & 0 & 0 \\
\hline & $2-6 b$ & 0 & 0 & 1 & 0 & 0 & 0 & 0 & 0 \\
\hline & $1-537$ & 0 & 0 & 1 & 0 & 0 & 0 & 0 & 0 \\
\hline & $1-539$ & 0 & 0 & 1 & 0 & 0 & 0 & 0 & 1 \\
\hline & $2-543$ & 0 & 0 & 1 & 0 & 0 & 0 & 0 & 1 \\
\hline \multirow[t]{2}{*}{ Transition } & $1-6$ & 1 & 1 & 1 & 1 & 1 & 1 & 1 & 0 \\
\hline & $1-7$ & 1 & 1 & 1 & 1 & 1 & 1 & 0 & 1 \\
\hline All & Sum & 14 & 16 & 21 & 12 & 14 & 14 & 11 & 11 \\
\hline
\end{tabular}

(a)

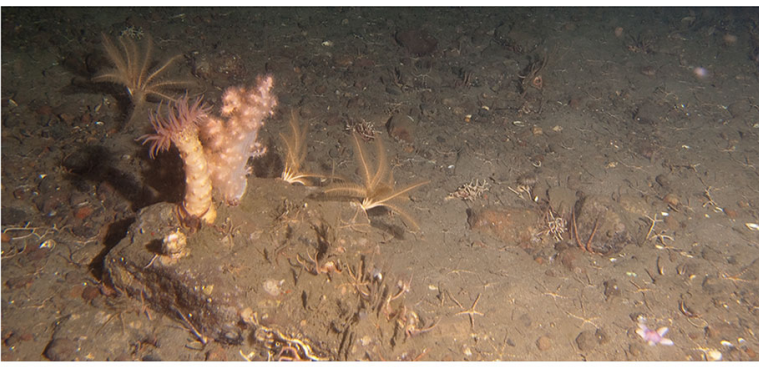

(b)

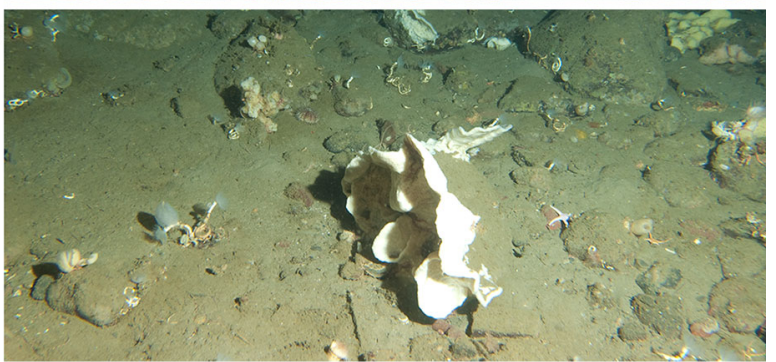

(c)

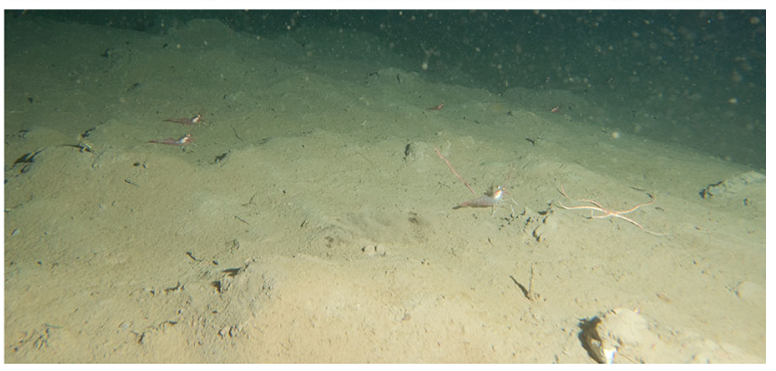

Fig. 4 Sample images taken off northern Svalbard in 2010, showing the seabed at a a shallow station (1-1, 80-110 m), b an intermediate station (1-2, 163-193 m) and $\mathbf{c}$ a deep station (1-5, 366-446 m)

fishes reached a maximum abundance of $0.2-0.1$ ind $\mathrm{m}^{-2}$, respectively. The quantitative faunal composition varied pronouncedly among stations, even at coarse taxonomic level. Ophiuroids and ascidians, for example, were dominant at some stations but absent at other stations.
The spatial pattern in the abundance data was very similar to that visible in the presence-absence data, except that three intermediate stations were clearly different from both one another and all other stations (Fig. 8). Again, there was a significant overall difference among the three depth zones (ANOSIM Global R: 0.448; $p=0.001$ ). Pairwise ANOSIM tests showed the shallow and intermediate depth zones to be more similar to one another than to the deep zone. Furthermore, as also in case for presenceabsence data (see above), the abundance-based biotic distribution pattern was significantly related to the amongstation variation in abiotic seabed composition, even though the correlation was clearly weaker (RELATE test $r=0.245 ; p=0.012$ ). The presence of stones, gravel and sand best explained the variations in faunal abundance $($ BEST analysis correlation $=0.388)$.

\section{Other findings}

Coralline red algae were found at a number of stations down to a water depth of $90 \mathrm{~m}$, mostly covering stones and shells (Table 5). A large amount of bivalve shells were found at station 2-10, covered with coralline red algae (Table 5).

At each station deeper than $286 \mathrm{~m}$, pronounced dents of approximately $50 \mathrm{~cm}$ width were recorded at the seafloor (Table 5). These marks (Fig. 9a) differed between stations in conspicuousness. They were often also characterized by excavated infaunal bottom fauna, mainly polychaetes (Fig. 9b).

\section{Discussion}

Our inventory of the epibenthic megafauna north of Svalbard extends the knowledge on the distribution and 
Fig. 5 Number of epibenthic megafauna taxa and faunal composition (at a coarse taxonomic level) in seabed images taken of northern Svalbard in 2010 and 2011, in three depth zones: a shallow, $\mathbf{b}$ intermediate and $\mathbf{c}$ deep (a)

Fish

Ascidiacea

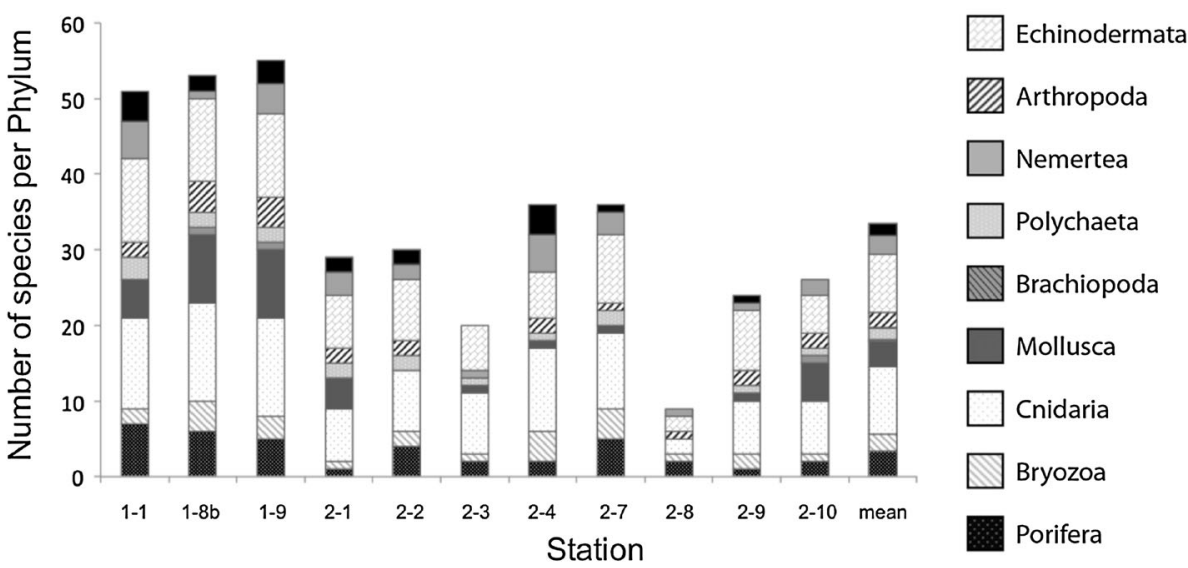

Fish

(b)

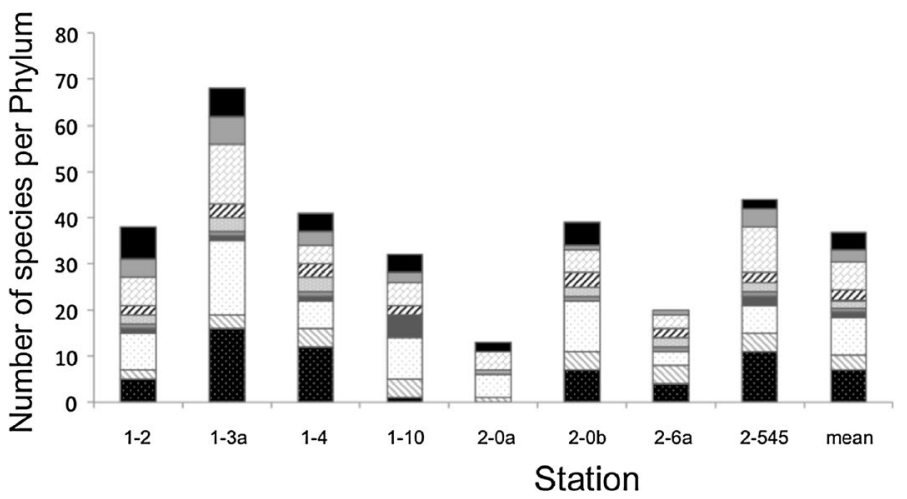

Ascidiacea

Echinodermata

Arthropoda

Nemertea

Polychaeta

Brachiopoda

Mollusca

Cnidaria

Bryozoa

Porifera

Fish

\section{(c)}

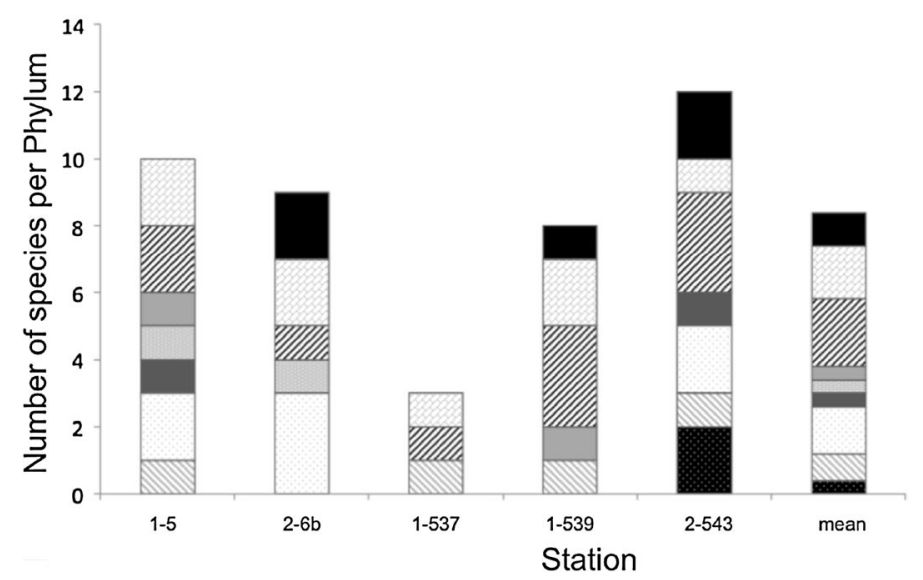

Ascidiacea

Echinodermata

Arthropoda

Nemertea

Polychaeta

Brachiopoda

Mollusca

Cnidaria

Bryozoa

Porifera 


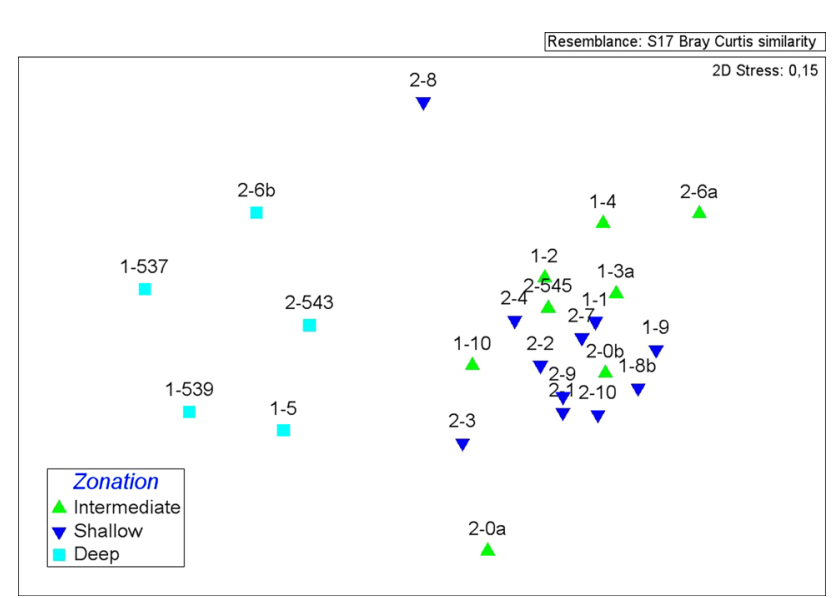

Fig. 6 MDS plot visualizing the pattern of Bray-Curtis resemblances among stations, computed using presence-absence data of epibenthic taxa recorded in seabed images taken off northern Svalbard in 2010 and 2011

composition of the benthos in this area, which was described the last time by Gulliksen et al. (1999) who summarized findings from many sources, including peerreviewed literature, cruise reports and personal observations. For our study area, they reported a total of 363 macro-organisms. Caution is advised when comparing our findings with these previous reports, since differences in sampling methods may lead to bias. First, the numbers published by Gulliksen et al. (1999) are based on many surveys, using a variety of sampling gear, and do not only include epibenthic organisms but also infaunal species. Our survey of epibenthic megafauna, however, was primarily based on seabed imaging. This sampling approach has clear advantages to conventional benthic sampling techniques, but there are also some important constraints that have to be considered in the interpretation of the results (Smith and Rumohr 2005). To begin with, image-based inventories are confined to the epibenthos. Moreover, rare species may not be represented in the data, due to limitations in sampling effort (here: number of images). Species accumulation curves constructed for the three depth zones (Fig. 10) illustrate diversity differences among depth zones and also suggest that $75 \%$ of the epibenthic taxa occurring in a zone would have been recorded by analyzing 63,49 and 60 images taken in the shallow, intermediate and deep zone, respectively.

From the 163 epibenthic taxa we identified in seabed images and AGT catches, almost half were identified to genus level. Out of these 84 identified genera, a total of 28 that we report in this survey (Table 6) were not recorded before in the study area (Gulliksen et al. 1999). For some taxa, such as Porifera, the mismatch can be explained by difficulties in identification, but also shifts in distribution ranges must be taken into account (Renaud et al. 2008). In some cases, it is evident that our findings add to the growing list of benthic species that extend their distribution boundaries northward. For instance, we identified the coralline red algae Lithothamnion sp. at two stations, in both AGT catches and seabed stills, at $80^{\circ} 33^{\prime} \mathrm{N}$ and $80^{\circ} 39^{\prime} \mathrm{N}$, respectively. This is the northernmost finding of these algae. Gulliksen et al. (1999) did not record it in our area but Teichert et al. (2012) reported it in the Nordkappbukta (Nordaustlandet, Svalbard) at $80^{\circ} 31^{\prime} \mathrm{N}$. Furthermore, one
Table 3 SIMPER analysis of presence-absences of megabenthic epifauna taxa in seabed images taken off northern Svalbard in 2010 and 2011 in three depth zones

Av. Abund, Average Abundance; Av. Sim, Average Similarity; Contrib. \%: contributed percentage; Cum. \%: cumulative contribution

\begin{tabular}{llllr}
\hline & Av. Abund $\left(\mathrm{ind}^{-2}\right)$ & Av. Sim $(\%)$ & Contrib. \% & Cum. \% \\
\hline Shallow & & & & \\
Ophiura sarsii & 1.00 & 3.23 & 7.46 & 7.46 \\
Strongylocentrotus sp. & 0.91 & 2.69 & 6.21 & 13.67 \\
Gersemia rubiformis & 0.91 & 2.37 & 5.47 & 19.15 \\
Hydroides norvergica & 0.91 & 2.37 & 5.47 & 24.62 \\
Ptychogastria polaris & 0.73 & 2.03 & 4.69 & 29.30 \\
Intermediate & & & & \\
Gersemia rubiformis & 1.00 & 2.93 & 7.67 & 7.67 \\
Hornera sp. & 0.88 & 1.94 & 5.07 & 12.74 \\
Ophiopholis aculeata & 0.88 & 1.94 & 5.07 & 17.81 \\
Hormathia sp. & 0.75 & 1.47 & 3.84 & 21.65 \\
Urticina sp. & 0.75 & 1.47 & 3.84 & 25.50 \\
Deep & & & & \\
Pandalus borealis & 1.00 & 12.56 & 36.76 & 36.76 \\
Ophiura sarsii & 1.00 & 12.56 & 36.76 & 73.52 \\
Exidmonea sp. & 0.6 & 3.02 & 8.84 & 82.36 \\
Nemertea indet. & 0.4 & 1.11 & 3.25 & 85.62 \\
Sabellida indet. & 0.4 & 1.05 & 3.08 & 88.70 \\
\hline
\end{tabular}


Fig. 7 a Number of taxa collected from Agassiz trawl catches and $\mathbf{b}$ match to taxa recorded in both seabed images and Agassiz trawl (AGT) catches taken off northern Svalbard in 2010 and 2011

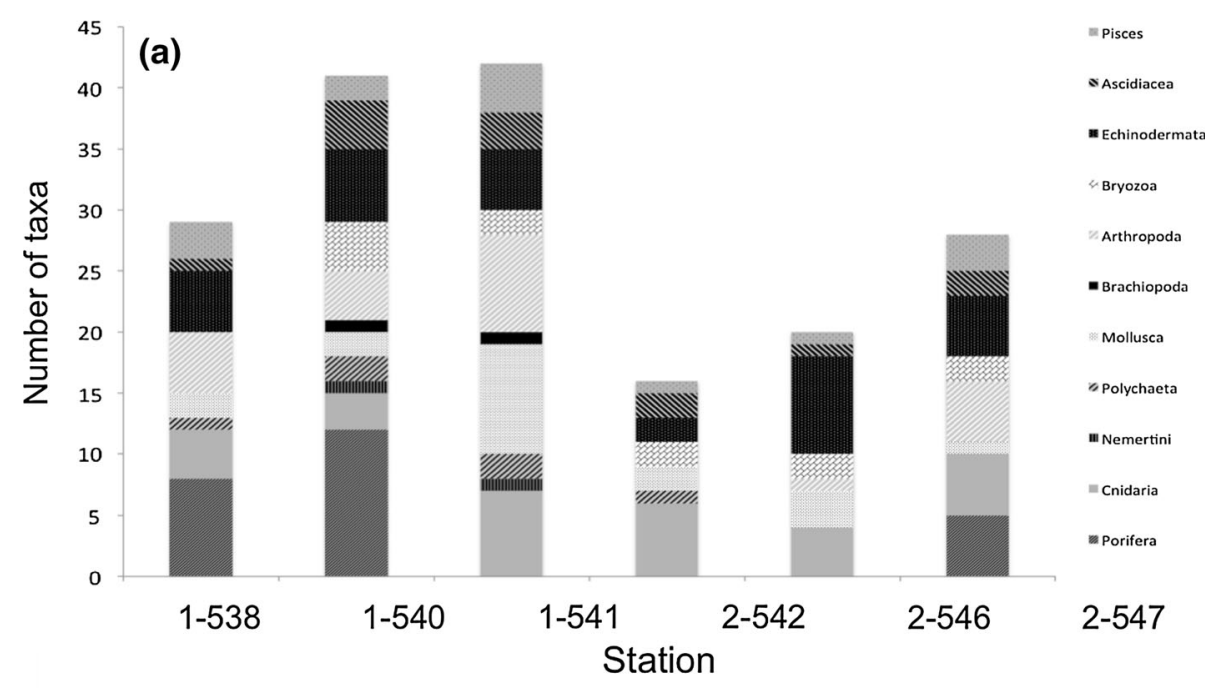

(b)

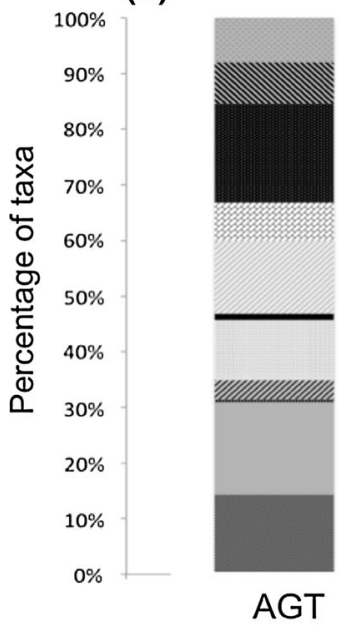

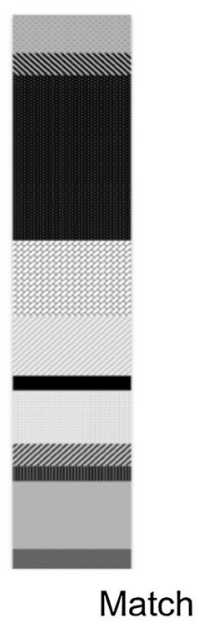

individual of the Atlantic king crab Lithodes maja, which is also not listed in the report of Gulliksen et al. (1999), was recorded at $80^{\circ} 32^{\prime} \mathrm{N}$.

As very often reported from marine field studies (e.g., Starmans et al. 1999), we found a pronounced depth zonation to be the most evident spatial pattern in our data, indicating that environmental factors that strongly vary with water depth are most important for determining the distribution of benthic species. There are a number of such factors that are well known as drivers of benthic community patterns, such as seabed composition (Graf 1992; Grebmeier et al. 2006) and food availability (Josefson 1987; Grebmeier et al. 1988; Graf 1992; Rosenberg 1995). According to Piepenburg (2005), seabed attributes are usually most significant at small (local) scales, while food supply to the benthos is the prime driver at larger (regional) scales. Differences in food availability are strongly related to water depth, hydrodynamics and various processes of particle transport (Graf 1992), resulting in an inverse relationship between sedimentation rates (and hence food supply to the benthos) and water depths (Suess 1980; Martin et al. 1987). This can also explain the exponential decline of the benthic standing stock from Arctic shelves to deep-sea basins (Curtis 1975).

Our findings are in general agreement with the longstanding notion that benthic species distribution is strongly affected by seafloor habitat structure (Snelgrove and Butman 1994). Moreover, substrate type can be used as a proxy of the bottom-current regime, with coarser sediments being indicative of higher velocities (Snelgrove and Butman 1994). A strong correlation between depth-related seabed composition and benthic distribution patterns was reported from several places, for instance, the shelves of the southeastern Chukchi Sea and northeastern Bering Sea (Feder et al. 1994). The most obvious difference is between hard-bottom and soft-bottom habitats. In hard-bottom communities of the Beaufort Sea, the limiting resource has been shown to be space, as sessile organisms cover most of 


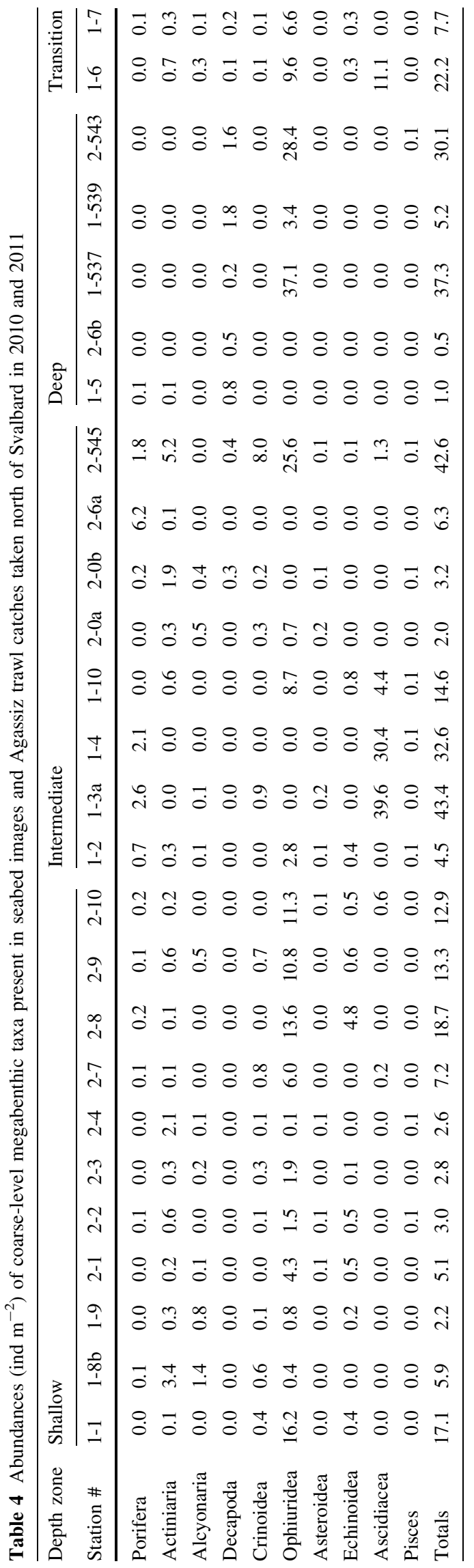

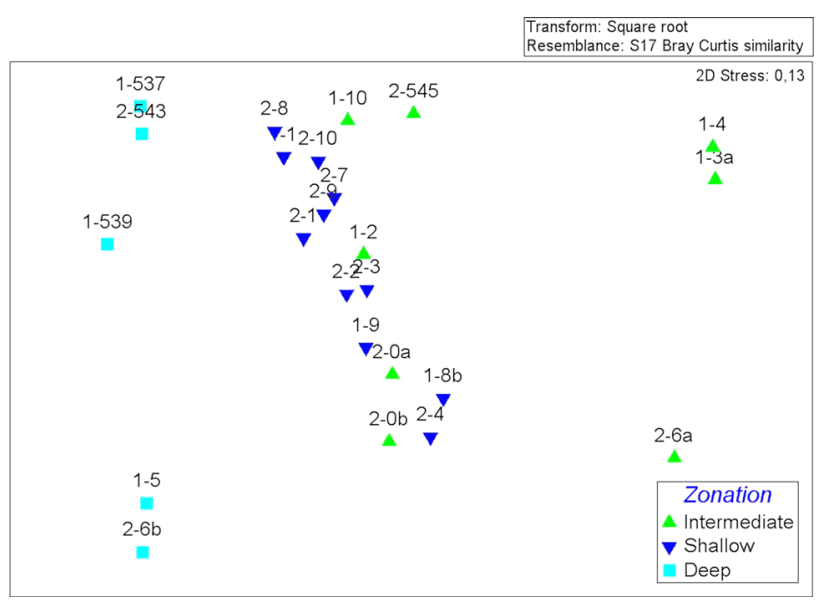

Fig. 8 MDS plot visualizing the pattern of Bray-Curtis resemblances among stations, computed using abundance data of epibenthic taxa recorded in seabed images taken off northern Svalbard in 2010 and 2011

Table 5 List of stations featuring pronounced seabed marks (putative trawl scours) or maerl recorded in seabed images taken off northern Svalbard in 2010 and 2011

\begin{tabular}{lll}
\hline Station \# & Water depth $(\mathrm{m})$ & Remarks \\
\hline $2-1$ & $51-87$ & Maerl \\
$2-9$ & 90 & Maerl \\
$2-10$ & $55-60$ & Shells/maerl \\
$1-5$ & $366-446$ & Dents \\
$1-537$ & 286 & Dents \\
$1-539$ & 350 & Dents \\
$1-7$ & $90-330$ & Dents \\
$2-543$ & 361 & Dents \\
$2-6 b$ & $368-405$ & Dents \\
\hline
\end{tabular}

the surfaces of hard substrates like boulders and stones (Konar and Iken 2005), whereas in Arctic soft-bottom communities, sediment grain size and homogeneity seem to be main drivers of faunal composition (Grebmeier and Barry 1991; Hop et al. 2002). As in our study, Arctic seabeds most often consist of a mixture of soft-bottom habitats (sediment) and hard-bottom substrates (e.g., boulders), the latter usually derived from ice-transport processes (Whittington et al. 1997; Lippert et al. 2001). The presence of hard-bottom habitats is particularly important for sessile and semi-sessile suspension feeders, which need special settling substrates (Levinton 1992). In general, more gravel, stones and boulders were found at the shallower stations in our field survey, providing suitable habitats for the attachment of sessile organisms and hence their associated fauna. Soft bottoms clearly prevailed at depths $>250 \mathrm{~m}$. There, the absence of boulders or 

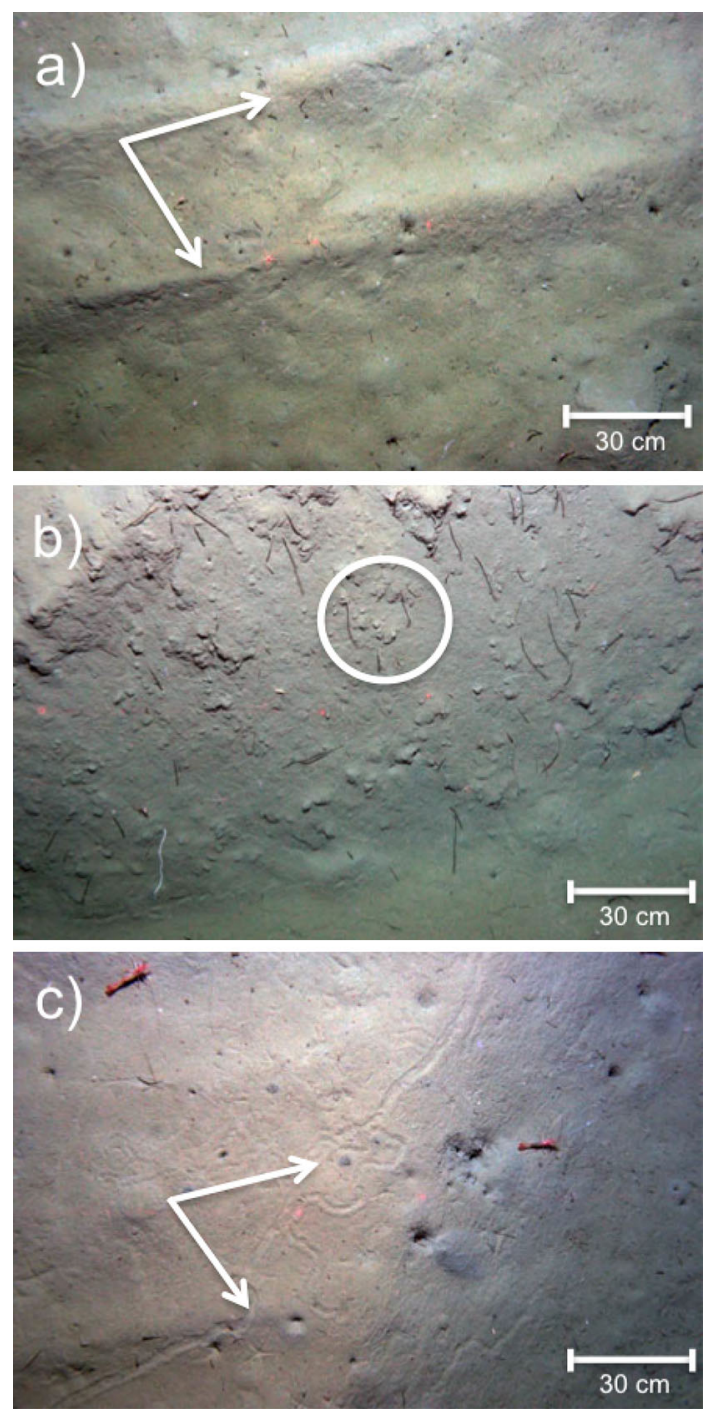

Fig. 9 Sample images of the seabed, taken off northern Svalbard in 2010 and 2011 at station 1-539 $(350 \mathrm{~m})$, showing a dents (putative trawl scours; arrows), b excavated fauna (circle) and c lebensspuren/ live tracks (arrows) rocks to attach to is certainly the main reason for the lack of sessile organisms.

A strong correlation with depth and seabed substrate was also detected for the abundances of the higher taxonomic groups in our study. We found high numbers of brittle stars, which are in general opportunistic species, at deep stations, where erect taxa like sponges, hydrozoans and bryozoans were virtually absent. High abundances of brittle stars have commonly been observed at Arctic shelves and slopes (Piepenburg 2005). In the Barents Sea, Ophiocten sericeum was most abundant, while Ophiura robusta dominated off Northeast Greenland (Piepenburg and Schmid 1996), and O. sarsii, which was also most common in our study, prevailed in the Chukchi Sea (Ambrose et al. 2001). Starmans et al. (1999) also reported brittle stars as being "the most important elements" of the megabenthos off Northeast Greenland (Starmans et al. 1999). Similar to our study, their analyses showed a clear separation between shallow shelves and deep troughs, with a transition zone in between. In contrast to our study, however, they reported low numbers of taxa with high abundances on the shelf and the opposite in the troughs. In our study, we found the opposite pattern with regard to taxonomic diversity (i.e., more taxa at shallow than at deep stations), while we could not identify a distinct pattern with regard to abundances because of the high among-station variability.

We hypothesize that the pronounced marks in the seabed detected at deeper stations (Fig. 9) are very likely scours caused by bottom-trawl doors hauled over the seabed. Differences in conspicuousness are probably a result of their "age": Less pronounced dents, such as those found at station 537, can surely be regarded to be older than very distinct ones, such as those recorded at station 539. Such evidence of trawling was found at all deep stations, which were characterized by soft bottoms and the occurrence of
Fig. 10 Species accumulation curves (based on two approaches: Sobs and Jackknife 1; see Clarke and Gorley 2006) for three depth zones, computed using species presence-absence data recorded in seabed images taken off northern Svalbard in 2010 and 2011

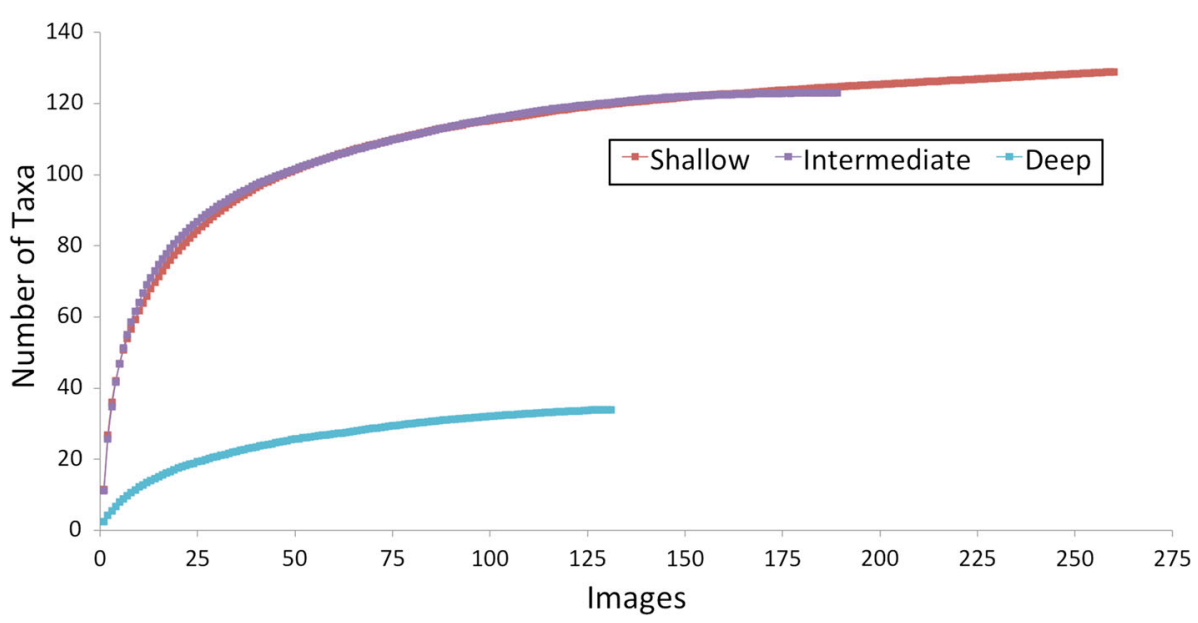


Table 6 List of megabenthic/ demersal genera and species that have not been reported in Gulliksen et al. (1999) from the region north of Nordaustlandet (Svalbard) and east of Hinlopenrenna (to $35^{\circ} \mathrm{E}$ )

\begin{tabular}{lll}
\hline Porifera & Polychaeta & Vertebrata \\
Axinella cf. rugosa & Hydroides norvegica & Anarhichas lupus \\
Axinella infundibuliformis & Filograna implexa & Anarhichas minor \\
Mycale lingua & Dentalium cf. dentalis & Chirolophis ascanii \\
Polymastia thielei & & Gadus morhua \\
Weberella bursa & Arthropoda & Lumpenus lampraeformis \\
& Eualus sp. & Melanogrammus aeglefinus \\
Cnidaria & & Pholis gunnelus \\
Alcyonium sp. & Echinodermata & Sebastes sp. \\
Bolocera tuediae & Hipasterias phrygiana & \\
Cerianthus lloydi & Psolus phantapus & \\
Drifa glomerata & Thyonidium cf. drummondi & \\
Bryozoa & Tunicata & \\
Exidmonea $\mathrm{sp}$. & Eudistoma vitreum & \\
Retepora $\mathrm{sp}$. & Molgula griffithsii & \\
\hline
\end{tabular}

Ambrose WG Jr, Clough LM, Tilney PR, Beer L (2001) Role of echinoderms in benthic remineralization in the Chukchi Sea. Mar Biol 139:937-949

Antipova TV (1975) Distribution of benthos biomass in the Barents Sea. PINRO Proc 35:121-124

Appeltans W, Bouchet P, Boxshall G, De Broyer C, de Voogd N, et al. (2012) World register of marine species. http://www. marinespecies.org. Accessed 20 June 2013

Bergmann M, Dannheim J, Bauerfeind E, Klages M (2009) Trophic relationships along a bathymetric gradient at the deep-sea observatory HAUSGARTEN. Deep-Sea Res I 56:408-424

Bergmann M, Soltwedel T, Klages M (2011) The interannual variability of megafaunal assemblages in the Arctic deep sea: preliminary results from the HAUSGARTEN observatory (79 N). Deep-Sea Res I 58:711-723

Beukema JJ, Cadée GC, Dekker R (2002) Zoobenthic biomass limited by phytoplankton abundance: evidence from parallel changes in two long-term data series in the Wadden Sea. J Sea Res 48:111-125

Blacker RW (1957) Benthic animals as indicators of hydrographic conditions and climate change in Svalbard waters. Fish Invest Ser 2:1-59

Blacker RW (1965) Recent changes in the benthos of the West Spitsbergen fishing grounds. Intern Comm Northw Atl Fish Spec Pub 6:791-794

Budaeva NE, Mokievsky VO, Soltwedel T, Gebruk AV (2008) Horizontal distribution patterns in the Arctic deep-sea macrobenthic communities. Deep-Sea Res I 55:1167-1178

Carroll ML, Cochrane S, Fieler R, Velvin R, White P (2003) Organic enrichment of sediments from salmon farming in Norway: environmental factors, management practices, and monitoring techniques. Aquaculture 226:165-180

Carroll ML, Denisenko SG, Renaud PE, Ambrose WG (2008) Benthic infauna of the seasonally ice-covered western Barents Sea: patterns and relationships to environmental forcing. Deep-Sea Res II 55:2340-2351

Clarke KR, Gorley RN (2006) PRIMER v6: user manual/tutorial. PRIMER-E, Plymouth

Cochrane S, Denisenko SG, Renaud PE, Emblow CS, Ambrose WG, Ellingsen IH, Skarðhamar J (2009) Benthic macrofauna and productivity regimes in the Barents Sea-ecological implications in a changing Arctic. J Sea Res 61:222-233

Curtis MA (1975) The marine benthos of Arctic and sub-Arctic continental shelves. a review of regional studies and their general results. Polar Rec 17:595-626 
Fautin DG (2012) Hexacorallians of the World. http://geoportal.kgs. ku.edu/hexacoral/anemone2/index.cfm. Accessed 20 Feb 2012

Feder HM, Foster NR, Jewett SC, Weingartner TJ, Baxter R (1994) Mollusks in the northeastern Chukchi Sea. Arctic 47:145-163

Graf G (1992) Benthic-pelagic coupling: a benthic view. Oceanogr Mar Biol Annu Rev 30:149-190

Grebmeier JM, Barry JP (1991) The influence of oceanographic processes on pelagic-benthic coupling in polar regions: a benthic perspective. J Mar Syst 2:495-518

Grebmeier JM, McRoy CP, Feder HM (1988) Pelagic-benthic coupling on the shelf of the northern Bering and Chukchi Seas. I. Food supply source and benthic biomass. Mar Ecol Prog Ser 48:57-67

Grebmeier JM, Cooper LW, Feder HM, Sirenko BI (2006) Ecosystem dynamics of the Pacific-influenced Northern Bering and Chukchi Seas in the Amerasian Arctic. Prog Oceanogr 71:331-361

Gröger J, Rumohr H (2006) Modelling and forecasting long-term dynamics of western Baltic macrobenthic fauna in relation to climate signals and environmental change. Neth J Sea Res 55:266-277

Gulliksen B, Svensen E (2004) Svalbard and life in polar oceans. Kom Forlag, Oslo

Gulliksen B, Palerud R, Brattegard T, Sneli J-A (1999) Distribution of marine benthic macro-organisms at Svalbard (including Bear Island) and Jan Mayen. Nor Dir Nat Manag, Oslo

Hiscock K (1996) Marine nature conservation review: rationale and methods. Joint Nature Conservation Committee, Peterborough

Holte B, Gulliksen B (1998) Common macrofaunal dominant species in the sediments of some north Norwegian and Svalbard glacial fjords. Polar Biol 19:375-382

Hop H, Pearson T, Hegseth EN, Kovacs KM, Wiencke C, Kwasniewski S, Eiane K, Mehlum F, Gulliksen B, WlodarskaKowalczuk M, Lydersen C, Weslawski JM, Cochrane S, Gabrielsen GW, Leakey RJG, Lønne OJ, Zajaczkowski M, Falk-Petersen S, Kendall M, Wängberg SA, Bischof K, Voronkov AY, Kovaltchouk NA, Wiktor J, Poltermann M, di Prisco G, Papucci C, Gerland S (2002) The marine ecosystem of Kongsfjorden, Svalbard. Polar Res 21:167-208

Hoste E, Vanhove S, Schewe I, Soltwedel T, Vanreusel A (2007) Spatial and temporal variations in deep-sea meiofauna assemblages in the Marginal Ice Zone of the Arctic Ocean. Deep-Sea Res I 54:109-129

IPCC (2007) Climate change 2007: the physical science basis. Contribution of working group I to the fourth assessment report of the intergovernmental panel on climate change. Cambridge University Press, Cambridge

Josefson AB (1987) Large-scale patterns of dynamics in subtidal macrozoobenthic assemblages in the Skagerrak: effects of a production-related factor? Mar Ecol Prog Ser 38:13-23

Kaiser MJ, Clarke KR, Hinz H, Austen MCV, Somerfield PJ, Karakassis I (2006) Global analysis of response and recovery of benthic biota to fishing. Mar Ecol Prog Ser 311:1-14

Kendall MA, Widdicombe S, Weslawski JM (2003) A multi-scale study of the biodiversity of the benthic infauna of the high latitude Kongsfjord, Svalbard. Polar Biol 26:383-388

Konar B, Iken K (2005) Competitive dominance among sessile marine organisms in a high Arctic boulder community. Polar Biol 29:61-64

Kröncke I (1995) Long term changes in North Sea benthos. Senckenb Marit 26:73-80

Kröncke I, Dippner JW, Heyen H, Zeiss B (1998) Long-term changes in macrofaunal communities off Norderney (East Frisia, Germany) in relation to climate variability. Mar Ecol Prog Ser 167:25-36

Kröncke I, Zeiss B, Rensing C (2001) Long-term variability in macrofauna species composition off the island of Norderney
(East-Frisia, Germany) in relation to changes in climatic and environmental conditions. Senckenb Marit 31:65-82

Levinton J (1992) The big bang of animal evolution. Sci Am 267:84-91

Lippert H, Iken K, Rachor E, Wiencke C (2001) Macrofauna associated with macroalgae in the Kongsfjord (Spitsbergen). Polar Biol 24:512-522

Martin JH, Knauer GA, Karl DM (1987) Vertex: carbon cycling in the northeast Pacific. Deep-Sea Res 34:267-285

Moen FE, Svensen E (2004) Marine fish and invertebrates of Northern Europe. AquaPress

Onarheim IH, Smedsrud LH, Ingvaldsen RB, Nilsen F (2014) Loss of sea ice during winter north of Svalbard. Tellus A 66:23933

Palomares MLD, Pauly D (eds) (2014) SeaLifeBase, version (01/ 2012). Pandalus borealis. http://www.org. Accessed 12 Feb 2014

Pearson TH, Barnett PRO (1987) Long-term changes in benthic populations in some west European coastal areas. Estuaries 10:220-226

Pearson TH, Mannvik HP (1998) Long-term changes in the diversity and faunal structure of benthic communities in the northern North Sea: natural variability or induced instability? Hydrobiologia 376:317-329

Pearson TH, Rosenberg R (1978) Macrobenthic succession in relation to organic enrichment and pollution of the marine environment. Oceanogr Mar Biol Annu Rev 16:229-331

Perry RI, Curry P, Brander K, Jennings S, Möllmann C, Planque B (2010) Sensitivity of marine systems to climate and fishing: concepts, issues and management responses. J Mar Syst 79:427-435

Piepenburg D (2005) Recent research on Arctic benthos: common notions need to be revised. Polar Biol 28:733-755

Piepenburg D, Schmid MK (1996) Brittle star fauna (Echinodermata: ophiuroidea) of the Arctic north-western Barents Sea: composition, abundance, biomass and spatial distribution. Polar Biol 16:383-392

Piepenburg D, Archambault P, Ambrose WG Jr, Blanchard A, Bluhm BA, Carroll ML, Conlan K, Cusson M, Feder HM, Grebmeier JM, Lévesque M, Petryashev V, Sejr M, Sirenko B, WłodarskaKowalczuk M (2011) Towards a pan-Arctic inventory of the species diversity of the macro- and megabenthic fauna of the Arctic shelf seas. Mar Biodiv 41:51-70

Reise K, Schubert A (1987) Macrobenthic turnover in the subtidal Wadden Sea: the Norderaue revisited after 60 years. Helgoland Mar Res 41:69-82

Renaud PE, Carroll ML, Ambrose WG Jr (2007) Effects of global warming on Arctic sea-floor communities and its consequences for higher trophic levels. In: Duarte CM, Agustí S (eds) Impacts of global warming on polar ecosystem. Fundación BBVA, Bilbao, pp 141-177

Renaud PE, Morata N, Carroll ML, Denisenko SG, Reigstad M (2008) Pelagic-benthic coupling in the western Barents Sea: processes and time scales. Deep-Sea Res II 55:2372-2380

Rosenberg R (1995) Benthic marine fauna structured by hydrodynamic processes and food availability. Neth $\mathrm{J}$ Sea Res 34:303-317

Sakshaug E (2004) Primary and secondary production in the Arctic Seas. In: Stein R, Macdonald RW (eds) The organic carbon cycle in the Arctic Ocean. Springer, Berlin, pp 57-81

Smith CJ, Rumohr H (2005) Imaging techniques. In: Eleftjeriou A, McIntyre A (eds) Methods for the study of marine benthos, 3rd edn. Blackwell, Oxford, pp 87-111

Snelgrove PVR, Butman CA (1994) Animal-sediment relationships revisited: cause versus effect. Oceanogr Mar Biol Annu Rev 32:111-177

Soltwedel T, Bauerfeind E, Bergmann M, Budaeva N, Hoste E, Jaeckisch N, Juterzenka K, Matthießen J, Mokievsky V, Nöthig 
E, Quéric N, Sablotny B, Sauter E, Schewe I, Urban-Malinga B, Wegner J, Wlodarska-Kowalczuk M, Klages M (2005) HAUSGARTEN: multidisciplinary investigations at a deep-sea, longterm observatory in the Arctic Ocean. Oceanography 18:46-61

Soltwedel T, Jaeckisch N, Ritter N, Hasemann C, Bergmann M, Klages M (2009) Bathymetric patterns of megafaunal assemblages from the arctic deep-sea observatory HAUSGARTEN. Deep-Sea Res I 56:1856-1872

Starmans A, Gutt J, Arntz WE (1999) Mega-epibenthic communities in Arctic and Antarctic shelf areas. Mar Biol 135:269-280

Stiansen JE, Korneev O, Titov O, Arneberg P, Filin A, Hansen JR, Høines $\AA$, Marasaev S (eds) (2009) Joint Norwegian-Russian environmental status 2008. Report on the Barents Sea ecosystem. Part II: complete report. IMR/PINRO Jt Rep Ser 2009(3):1-375

Suess E (1980) Particulate organic carbon flux in the oceans-surface productivity and oxygen utilization. Nature 288:260-265

Sweetman A, Chapman A (2011) First observations of jelly-falls at the seafloor in a deep-sea fjord. Deep-Sea Res I 58:1206-1211

Teichert S, Woelkerling W, Rüggeberg A, Wisshak M, Piepenburg D, Meyerhöfer M, Form A, Büdenbender J, Freiwald A (2012) Rhodolith beds (Corallinales, Rhodophyta) and their physical and biological environment at $8031^{\prime} \mathrm{N}$ in Nordkappbukta (Nordaustlandet, Svalbard Archipelago). Phycologia 51:371-390

Tunberg BG, Nelson WG (1998) Do climatic oscillations influence cyclical patterns of soft bottom macrobenthic communities on the Swedish west coast? Mar Ecol Progr Ser 170:85-94

Underwood AJ (1996) Detection, interpretation, prediction and management of environmental disturbances: some roles for experimental marine ecology. J Exp Mar Biol Ecol 200:1-27 van Oevelen D, Bergmann M, Soetaert K, Bauerfeind E, Hasemann C, Klages M, Schewe I, Soltwedel T, Budaeva N (2011) Carbon flows in the benthic food web at the deep-sea observatory HAUSGARTEN (Fram Strait). Deep-Sea Res I 58:1069-1083

Wassmann P, Reigstad M, Haug T, Rudels B, Carroll ML, Hop H, Gabrielsen GW, Falk-Petersen S, Denisenko SG, Arashkevich E, Slagstad D, Pavlova O (2006) Food webs and carbon flux in the Barents Sea. Progr Oceanogr 71:232-287

Weslawski JM, Wlodarska-Kowalczuk M, Legezynska J (2003) The occurrence of soft bottom macrofauna along the depth gradient in the High Arctic, 79 N. Pol Polar Res 23:73-88

Whittington RJ, Forsberg CF, Dowdeswell JA (1997) Seismic and side-scan sonar investigations of recent sedimentation in an iceproximal glacimarine setting, Kongsfjorden, north-west Spitsbergen. In: Davies TA et al (eds) Glaciated continental margins-an atlas of acoustic images. Chapman and Hall, London, pp 175-178

Wlodarska-Kowalczuk M, Pearson TH (2004) Soft-bottom macrobenthic faunal associations and factors affecting species distributions in an Arctic glacial fjord (Kongsfjord, Spitsbergen). Polar Biol 27:155-167

Wlodarska-Kowalczuk M, Weslawski JM, Kotwicki L (1998) Spitsbergen glacial bays macrobenthos-a comparative study. Polar Biol 20:66-73

Zenkevich LA (1963) The biology of the seas of the USSR. Academy of Science of the USSR, Moscow 